Autor ma trudności z wyborem konwencji, gdyż zaczyna książkę tekstem beletrystycznym, by wnet przejść do relacji o badaniach tekstu. Pewną nieufność względem jego wywodów wzmaga fakt ich znacznego powiązania z polityką.

Nie łagodzą takiej bardzo krytycznej oceny żarliwe zapewnienia autora, iż dzięki tym „odkryciom” wielu Żydów powraca do tradycji, a może i do wiary. Oby tak było! W polskim środowisku są jednak sygnały, iż ta książka jest szczególnie rozchwytywana przez zwolenników różnych sekt. Nie wydaje się więc, iż będzie ona prowadzić do przyjęcia przesłania Biblii. Traktując bowiem Biblię jako księgę wróżb raczej odwraca uwagę od jej przesłania. Dlatego jest to książka nie tylko bałamutna, ale i niebezpieczna.

Oltarzew

KS. JULIAN WARZECHA SAC

\title{
POLSKIE MESOPOTAMICA (PRZEGLĄD)
}

\section{STEFAN ZAWADZKI, Mane Tekel Fares. Źródta do dziejów Babilonii chal- dejskiej, Wydawnictwo Naukowe UAM, Poznań 1996, s. 118.}

Egzegetów Starego Testamentu zainteresuje wybór tekstów akadyjskich w thumaczeniu poznańskiego historyka Stefana Zawadzkiego. Jest to praca pionierska w literaturze polskojęzycznej. Ważne dla egzegezy biblijnych tekstów apokaliptycznych są mezopotamskie teksty prorockie (s. 52-57), jak również ,nabonidiana", czyli teksty o Nabonidzie (s. 80-118), mające związek z Dn 3, 31 - 4, 34.

2. STEFAN ZAWADZKI, Ze studiów nad chronologia Babilonii (koniec VII początek V wieku przed Chr.), Poznańskie Towarzystwo Przyjaciół Nauk, Wydzial Historii i Nauk Społecznych, Prace Komisji Historycznej, T. 53, Poznań 1997, s. 96.

Tegoż autora zbiór studiów z dziedziny chronologii babilońskiej, które wnoszą wiele ważnych danych do interpretacji pism biblijnych. I tak: na s. 25 znajdujemy wyjaśnienie do $2 \mathrm{Krl} 23,29 \mathrm{n}$ (problem Necho). Na ten temat istnieje bogata bibliografia, a swego czasu (1956-1957) rektor Biblicum E. Vogt napisał o tym parę artykułów, ze szwajcarską dokładnością wyliczając trasę i czas marszu wojsk. Na s. 41 jest odniesienie do Dn 4, 25-34 (upokorzenie Nabuchodonozora kwestionowane przez historyków), zaś s. 43 dostarcza wiadomości odnoszących się do tekstu $2 \mathrm{Krl} 25,27-30$.

Zarówno ta publikacja, jak i poprzednia to owoc studiów autora w British Museum w latach 1994-1996. 
3. JAROSŁAW MANIACZYK, Traktat sukcesyjny Asarhaddona króla Asyrii (681-669 p.n.e.), Wydawnictwo Naukowe UAM, Poznań 1997, s. 56.

Otrzymaliśmy zbiór tekstów przyswojonych językowi polskiemu na podstawie najnowszych opracowań obcojęzycznych, tekstów, które zainteresują nie tylko historyków starożytności, ale także biblistów, ponieważ dotyczą okresu panowania Manassesa i sprowadzenia osadników pogańskich do Samarii (stąd później Samarytanie). Ponadto odzwierciedlają dobrze mentalność Asyryjczyków, co przydaje się przy egzegezie tekstów biblijnych odnoszących się do tej epoki.

Kraków

KS. JERZY CHMIEL 